Review Article

\title{
Efficiency, Safety, and Efficacy of High-Power Short-Duration Radiofrequency Ablation in Patients with Atrial Fibrillation
}

\author{
Xuerong Sun, ${ }^{1}$ Jiang Lu, ${ }^{2}$ Jinxuan Lin, ${ }^{1}$ Tianjie Feng, ${ }^{1}$ Ni Suo, ${ }^{1}$ Lihui Zheng, ${ }^{1}$ Zhimin Liu, ${ }^{1}$ \\ Gang Chen, ${ }^{1}$ Xiaohan Fan, ${ }^{1}$ Shu Zhang, ${ }^{1}$ and Guodong Niu (1) ${ }^{1}$ \\ ${ }^{1}$ Arrhythmia Center, State Key Laboratory of Cardiovascular Disease, Fuwai Hospital, \\ National Center for Cardiovascular Diseases, Chinese Academy of Medical Sciences, Peking Union Medical College, \\ Beijing 100037, China \\ ${ }^{2}$ Arrhythmia Center, Fuwai Yunnan Cardiovascular Hospital, Kunming 650102, China \\ Correspondence should be addressed to Guodong Niu; guodniu@163.com
}

Received 4 September 2020; Revised 14 December 2020; Accepted 19 December 2020; Published 16 February 2021

Academic Editor: Giovanni Battista Forleo

Copyright (C) 2021 Xuerong Sun et al. This is an open access article distributed under the Creative Commons Attribution License, which permits unrestricted use, distribution, and reproduction in any medium, provided the original work is properly cited.

\begin{abstract}
Pulmonary vein isolation (PVI) is the cornerstone therapy of atrial fibrillation (AF). Radiofrequency catheter ablation (RFCA) is performed using a point-by-point method to achieve durable PVI. However, this procedure remains complex and time-consuming, and the long-term clinical outcomes are still not satisfactory. Recently, there has been increasing interest in the clinical application of high-power short-duration (HPSD) approaches in the field of RFCA. HPSD ablation, distinguishing it from the conventional ablation strategy, delivers RF energy at a high power and saves the dwell time at each site. It is unknown whether the HPSD approach can bring some gratifying changes in the field of RF energy ablation. A number of experimental studies and clinical studies have been conducted regarding this topic. The review aimed to summarize the research findings and evaluate the procedural efficiency, safety, and clinical outcomes of the HPSD approach based on the evidence available to date.
\end{abstract}

\section{Introduction}

Pulmonary vein isolation (PVI) is the cornerstone of current ablation strategies for the treatment of symptomatic atrial fibrillation (AF) [1-3]. Pulmonary vein (PV) reconnection is the major reason for AF recurrence $[4,5]$. Durable PVI can be performed by radiofrequency catheter ablation (RFCA) using a point-by-point method [5]. However, this process is complex and time-consuming, especially when compared with cryoballoon ablation (CBA) and pulse field ablation (PFA) $[3,6]$. Additionally, procedure-related complications, such as esophageal damage, stream pops, and cardiac tamponade, still remain a concern [3]. Thus, technological renovation is required to improve procedural efficiency, efficacy, and safety in the field of RFCA.

Recent published data showed that RF energy can be delivered at 45 to $90 \mathrm{~W}$ for shorter durations aiming for contiguous lines and transmural lesions, especially owing to the development of novel open-irrigated catheters [7-9].
High-power short-duration (HPSD) approach is different from the conventional ablation therapy (CAT) at the ablation settings. CAT is usually performed at 25 to $40 \mathrm{~W}$ delivered for 20 to $60 \mathrm{~s}[10,11]$. Theoretically, the HPSD approach appears feasible and leads to an efficient PVI by shortening the RF application. However, it remains a considerable concern whether the HPSD approach can achieve comparable or superior outcomes without compromising safety. A number of experimental and clinical studies have been conducted to evaluate its efficacy and safety. This article reviews the experimental findings and clinical outcomes of HPSD ablation.

\section{In Vivo and In Vitro Ablation Studies on HPSD}

An in vitro study on porcine left ventricular myocardium indicated that RF delivery at a higher power (40 to $50 \mathrm{~W}$ ), shorter duration (5 to $10 \mathrm{~s}$ ), and low irrigation flow rate 
$(2 \mathrm{ml} / \mathrm{min})$ with $20 \mathrm{~g}$ contact force $(\mathrm{CF})$ was anticipated reliably to create transmural lesions of the posterior left atrial wall in patients with AF [12]. Steam pops were observed usually when the irrigation flow rate was $2 \mathrm{~mL} / \mathrm{min}$, power 40-50 W, and ablation duration 20-40 s. Meanwhile, the tissue temperature monitoring at a $5 \mathrm{~mm}$ depth with HPSD $\left(50 \mathrm{~W}\right.$ for $5 \mathrm{~s}$ ) was lower than $50^{\circ} \mathrm{C}$ (the temperature at which irreversible injury happens), which suggested that HPSD RF ablation may be safer in preventing collateral damage to neighboring structures. Another study based on in vitro and in vivo sheep models observed that an ablation setting of $50-80 \mathrm{~W}$ for $5 \mathrm{~s}$ adequately achieved the similar lesion depth of 2-3 mm (atrial wall thickness based on a human autopsy series) with $10 \mathrm{~g} \mathrm{CF}$ at an irrigation flow rate of $30 \mathrm{ml} / \mathrm{min}$ [13]. In addition, an ablation setting of $50-60 \mathrm{~W}$ for $5 \mathrm{~s}$ reduced the incidence of steam pops and collateral damage to neighboring structures compared with the conventional ablation setting of $40 \mathrm{~W}$ for $30 \mathrm{~s}$.

Recently, a novel open-irrigated catheter, QDOTMI$\mathrm{CRO}^{\mathrm{TM}}$ catheter, developed on a similar platform of the Thermocool SmartTouch SF catheter, with 56 irrigation holes through the $3.5 \mathrm{~mm}$ tip for an improved irrigation system and six symmetrical temperature sensors for accurate real-time temperature monitoring at the catheter-tissue interface, contributed to the clinical application of a very high-power ablation setting of $90 \mathrm{~W}$ for $4 \mathrm{~s}$ [10]. Previous in vivo studies that were performed showed that, compared with CAT, for a single ablation lesion and linear atrial lines, an ablation setting of $90 \mathrm{~W}$ for $4 \mathrm{~s}$ resulted in larger lesion diameters, similar depth, and contiguous lines without apparent gaps, ensuring better contiguity and transmurality [11]. It was shown that this HPSD approach modified the relationship between resistive and conductive heating, avoiding potential collateral damage to adjacent structures by limiting conductive heating (Figure 1). The results of the in vitro and in vivo studies on HPSD ablation are summarized in Table 1.

\section{HPSD Ablation Setting and Lesion Endpoint}

The ideal HPSD ablation setting should be determined according to the requirements of the lesion transmurality, linear ablation contiguity, and safety issues, including but not limited to RF power, duration, CF, irrigation flow rate, impedance drop, catheter stability, temperature measurement, and interlesion distance (ILD) [5]. Because of the limitation that HPSD ablation lesions vary greatly in a range of rather short RF durations, identifying a valid parameter capable of predicting the lesion size is essential. There have been various lesion endpoints of energy delivery at each site developed in different studies, including the combination of RF power and dwell time, unipolar signal modification, impedance drop, loss of pacing during RF delivery, and some defined ablation lesion markers such as lesion size index (LSI) and ablation index (AI) [14-19].

HPSD RF ablation was usually delivered at a high or very high power of $50-90 \mathrm{~W}$ for less than $10 \mathrm{~s}$. The combination of RF power and dwell time ( $90 \mathrm{~W}$ for $4 \mathrm{~s}, 50 \mathrm{~W}$ for $5-7 \mathrm{~s}$, etc.) was used as a common lesion endpoint to predict the lesion volume. A quantitative ablation strategy was developed into a proper ablation lesion marker composed of important lesion information. Force-time integral (FTI), an integral of $\mathrm{CF}$ and $\mathrm{RF}$ duration, was previously used for $\mathrm{AF}$ ablation but did not contain RF power, which had a considerable contribution to the ablation lesion volume [14]. Other than FTI, LSI and AI, including CF, RF duration, and $\mathrm{RF}$ power in different weighted formulas, were estimated as convincing ablation lesion markers for guiding RF ablation and decreasing the long-term PV reconnection rate $[15,20]$. It was observed that the CLOZE standard of AI targets of $\geq 400$ for the posterior wall and $\geq 550$ for the anterior wall with $6 \mathrm{~mm}$ ILD was used to guide PVI in paroxysmal AF ablation and can achieve excellent results of $92.3 \%$ singleprocedure 12-month freedom [5]. Some studies also showed that high power $(40-50 \mathrm{~W})$ ablation guided by AI appeared to be a feasible, effective, and safe technique for PVI in patients with AF. However, AI is still not a reliable marker for the HPSD approach. It was commonly observed that, at high power delivered, the initial AI value displayed is already $>400$, probably due to time-consuming confirmation of catheter stability. In addition, as shown by Chinitz et al. [16], an impedance drop of more than $10 \Omega$ during ablation was associated with a durable transmural lesion. It was also suggested that the complete elimination of the negative component of the unipolar atrial signal (a change from the initial RS pattern to the final $\mathrm{R}$ pattern) reflects an established transmural lesion [17-19]. The HPSD RF ablation settings and lesion endpoints in published clinical studies are demonstrated in Table 2 [21-35].

In addition, to reduce conductive heat transfer and avoid collateral injury to surrounding structures, it is recommended to reduce the application of total energy at the posterior left atrial wall (shorter duration or lower RF power compared with the anterior wall) when using the HPSD approach.

\section{Procedural Efficiency}

The RF ablation time with HPSD approach is remarkably reduced compared with conventional ablation, which is confirmed by all the published studies on HPSD ablation versus CAT [24-27, 29-32]. Only two out of nine studies $[21,24,26,27,29-32,34]$ showed that the procedure time was not remarkably shorter in the HPSD group than in the CAT group. The procedural efficiency is mainly due to the reduction of RF dwell time at each site with high-power delivery. The reduction in mean procedure time was less than the sole reduction in mean RF ablation time. It was reported that the mean procedure time during HPSD ablation was reduced by $12-39 \%$, while the mean RF ablation time was reduced by $36-65 \%$. RF ablation time and procedure time were saved mainly owing to the high-power delivery and the improved first-pass isolation rate. As for the fluoroscopy time, $50 \%$ of studies (four out of eight) [21, 24-27, 30-32, 34] showed that HPSD ablation took a shorter fluoroscopy time than CAT and that heterogeneity might be associated with the operator' $s$ experience, HPSD approach workflow, different mapping and ablation techniques, a wide range of ablation power, and different ablation strategies. 
High-power short-duration approach

$(45 \mathrm{~W}-90 \mathrm{~W} / 5 \mathrm{~s}-15 \mathrm{~s})$

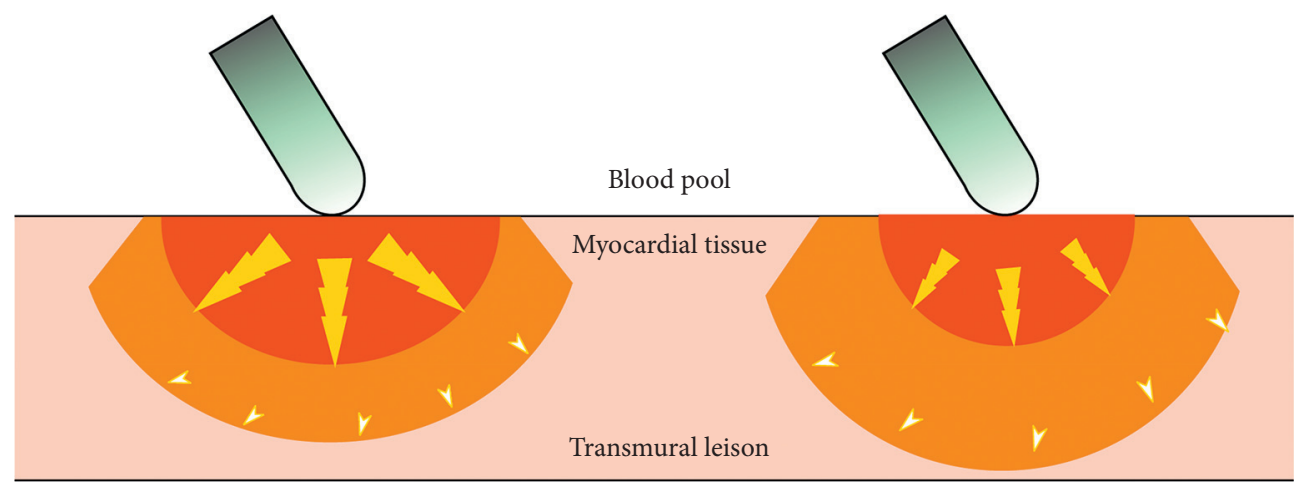

Conventional ablation therapy

$(25 \mathrm{~W}-40 \mathrm{~W} / 20 \mathrm{~s}-60 \mathrm{~s})$

Collateral injury

Resistive heating

Conductive heating

FIGURE 1: Comparison between HPSD approach and CAT. Lesion dimensions of radiofrequency ablation and heating distribution in myocardial tissue are demonstrated. HPSD approach and CAT could create comparable lesion size. HPSD approach results in an ablation lesion that is heated directly from the catheter during the resistive phase (red part), while, in CAT, myocardial tissue is largely heated because of conductive heating (golden yellow part).

The procedural efficiency of HPSD ablation has a number of benefits. Shorter procedures limit patient exposure to anesthesia and intravenous fluids with lower procedure-related complication rates, especially for patients with potential heart failure, possibly contributing to a safer procedure. Decreased fluoroscopy time is beneficial to patients, operators, and supporting staff. Most importantly, when a shorter RF dwell time at each site is applied, catheter stability is much easier to maintain, which makes it much more suitable for unskilled operators. Clinical efficiency between HPSD group and CAT group was compared in Table 3.

\section{Clinical Efficacy}

For the acute PVI outcomes, four out of five studies $[25,26,29,30,33]$ reported that the HPSD approach contributed to a significantly higher first-pass ipsilateral PVI rate, while three out of five studies [25, 29-31,34] observed a significantly lower acute PV reconnection rate compared with CAT, which can also help reduce the RF ablation time to achieve complete PVI and improve procedural efficiency. Table 3 summarized the clinical efficacy between HPSD group and CAT group.

With regard to long-term outcomes, it is controversial whether HPSD ablation can achieve superior clinical outcomes compared with conventional ablation. Five studies $[21,24,27,31,34]$ reported the one-year AF recurrence rate between HPSD ablation and conventional therapy. It was shown that, in the study population with only PAF, the AF recurrence rate was remarkably lower in the HPSD group than in the CAT group, while, in the study population with combined PAF and PsAF, the HPSD group did not have dominant advantages over the CAT group. The variety of AF types and ablation strategies used may have contributed to this. Until now, the longest follow-up duration between HPSD ablation and conventional ablation is three years, showing that the recurrence AF rate was similar $(26.5 \%$ vs. $30.7 \% ; P=0.23$ ) [21].

Shin et al. [34] performed a randomized controlled trial and found that the 12-month freedom rate from AF was not significantly different between the HPSD $(50 \mathrm{~W})$ and conventional groups $(P=0.862)$. They also reported on the risk factors for $\mathrm{AF}$ recurrence. In the multivariate analysis, nonPAF (hazard ratio $[\mathrm{HR}] 2.836, P=0.045)$ and AI (HR 0.983, $P=0.001)$ were independent risk factors for AF recurrence.

\section{Safety and Complications}

There is a major concern for procedure-related complications with the HPSD approach and whether the procedural efficiency and efficacy outcomes come at a cost of safety. Experimental studies demonstrated that the HPSD approach created a shallower and broader lesion but appeared to have a narrow safety and efficacy window [10-13]. Thus, the RF duration for the HPSD approach is the critical determinant of lesion formation. When the ablation is insufficient, superficial and nontransmural lesions are created; when the ablation is excessive, collateral damage (including injury to the esophaus annd phrenic nerve), steam pops, and subsequent pericardial tamponade could ooccur. Silent and clinical stroke, as a result of thrombus formation, may also occur.

Wrinkle et al. [36] reported extremely low complication rates and a very low incidence $(0.0087 \%)$ of atrioesophageal fistulas with HPSD approach for $45-50 \mathrm{~W}$ in a cohort of 11,436 patients in four experienced centers. Bunch et al. [21] 
TABLE 1: In vitro and in vivo studies on HPSD ablation.

\begin{tabular}{|c|c|c|c|c|c|c|c|c|}
\hline Study & $\begin{array}{l}\text { In vitro or in } \\
\text { vivo model }\end{array}$ & $\begin{array}{l}\text { Catheter } \\
\text { type }\end{array}$ & $\begin{array}{c}\text { Ablation } \\
\text { setting } \\
(\mathrm{W} / \mathrm{s})\end{array}$ & $\begin{array}{l}\text { Irrigation flow } \\
\text { rate }(\mathrm{ml} / \mathrm{min})\end{array}$ & $\begin{array}{l}\text { Contact } \\
\text { force }(g)\end{array}$ & $\begin{array}{l}\text { Lesion } \\
\text { depth } \\
(\mathrm{mm})\end{array}$ & $\begin{array}{l}\text { Lesion } \\
\text { width } \\
(\mathrm{mm})\end{array}$ & $\begin{array}{c}\text { Stream } \\
\text { pops } \\
(\%) \\
\end{array}$ \\
\hline \multirow{6}{*}{$\begin{array}{l}\text { Bhaskaran } \\
\text { et al. [12] }\end{array}$} & \multirow{6}{*}{$\begin{array}{l}\text { In vitro and in } \\
\text { vivo model: } \\
\text { sheep RA } \\
\text { myocardium }\end{array}$} & $\begin{array}{l}\text { Thermocool catheter (in } \\
\text { vitro) }\end{array}$ & $\begin{array}{c}\text { In vitro } \\
\text { model: } \\
40 / 30 \\
40 / 5 \\
50 / 5 \\
60 / 5 \\
70 / 5 \\
80 / 5\end{array}$ & 30 & 10 & $\begin{array}{c}\text { In vitro } \\
\text { model: } \\
2.7 \\
1.3 \\
2.2 \\
2.4 \\
2.6 \\
2.9\end{array}$ & $\begin{array}{c}\text { In vitro } \\
\text { model: } \\
5.2 \\
4.1 \\
5.1 \\
5.4 \\
5.9 \\
6.5\end{array}$ & - \\
\hline & & \multirow{5}{*}{$\begin{array}{c}\text { Thermocool SmartTouch } \\
\text { catheter (in vivo) }\end{array}$} & $\begin{array}{l}\text { In vivo: } \\
40 / 30\end{array}$ & \multirow{5}{*}{30} & \multirow{5}{*}{10} & $\begin{array}{c}\text { In vivo: } \\
2.4\end{array}$ & $\begin{array}{c}\text { In vivo: } \\
9.1\end{array}$ & \multirow{5}{*}{$\begin{array}{c}\text { In vivo: } \\
2 / 19 \\
(10.5) \\
0 / 18(0) \\
0 / 14(0) \\
1 / 12(8) \\
1 / 9(11)\end{array}$} \\
\hline & & & $50 / 5$ & & & 2.3 & 7.6 & \\
\hline & & & $60 / 5$ & & & 2.2 & 7.7 & \\
\hline & & & $70 / 5$ & & & 2.1 & 7.5 & \\
\hline & & & $80 / 5$ & & & 2.4 & 8.3 & \\
\hline \multirow{16}{*}{$\begin{array}{l}\text { Ali-Ahmed } \\
\text { et al. [13] }\end{array}$} & \multirow{16}{*}{$\begin{array}{l}\text { In vitro model: } \\
\text { porcine LV } \\
\text { myocardium }\end{array}$} & \multirow{16}{*}{$\begin{array}{l}\text { Thermocool SmartTouch } \\
\text { catheter }\end{array}$} & $20 / 5$ & \multirow{5}{*}{2} & \multirow{16}{*}{20} & 1.4 & 5.1 & \multirow{16}{*}{-} \\
\hline & & & $30 / 5$ & & & 2.1 & 5.7 & \\
\hline & & & $40 / 5$ & & & 2.4 & 6.6 & \\
\hline & & & $50 / 5$ & & & 2.9 & 7.2 & \\
\hline & & & $20 / 5$ & & & 1.7 & 4.2 & \\
\hline & & & $30 / 5$ & \multirow{4}{*}{17} & & 1.7 & 5.9 & \\
\hline & & & $40 / 5$ & & & 2.6 & 6.4 & \\
\hline & & & $50 / 5$ & & & 3.0 & 7.3 & \\
\hline & & & $20 / 10$ & & & 2.6 & 6.7 & \\
\hline & & & $30 / 10$ & \multirow{4}{*}{2} & & 3.0 & 7.9 & \\
\hline & & & $40 / 10$ & & & 4.1 & 8.7 & \\
\hline & & & $50 / 10$ & & & 5.0 & 9.1 & \\
\hline & & & $20 / 10$ & & & 1.9 & 5.6 & \\
\hline & & & $30 / 10$ & \multirow{3}{*}{17} & & 2.8 & 6.9 & \\
\hline & & & $40 / 10$ & & & 3.7 & 7.8 & \\
\hline & & & $50 / 10$ & & & 4.9 & 7.9 & \\
\hline $\begin{array}{l}\text { Barkagan } \\
\text { et al. [10] }\end{array}$ & In vitro model & $\begin{array}{l}\text { Thermocool SmartTouch } \\
\text { SF catheter (conventional } \\
\text { ablation) } \\
\text { QDOTMICRO }{ }^{\mathrm{TM}} \text { catheter } \\
\text { (HPSD ablation) }\end{array}$ & $30 / 30$ & 8 & $10-20$ & Transmural & $\begin{array}{c}\text { Posterior } \\
\text { line } \\
7.9 \\
9.5 \\
\text { Anterior } \\
\text { line } \\
3.6 \\
8.0\end{array}$ & 0 \\
\hline \multirow{4}{*}{$\begin{array}{l}\text { Leshem et al. } \\
\text { [11] }\end{array}$} & \multirow{3}{*}{$\begin{array}{l}\text { In vitro model: } \\
\text { swine thigh } \\
\text { muscle }\end{array}$} & \multirow{3}{*}{$\begin{array}{l}\text { Thermocool SmartTouch } \\
\text { SF catheter (conventional } \\
\text { ablation) } \\
\text { QDOTMICRO }^{\mathrm{TM}} \text { catheter } \\
\text { (HPSD ablation) }\end{array}$} & $\begin{array}{c}25 / 20 \\
90 / 4\end{array}$ & \multirow{3}{*}{8} & \multirow{3}{*}{10} & $\begin{array}{l}3.74 \\
3.62\end{array}$ & $\begin{array}{c}6.3 \\
10.36\end{array}$ & \multirow{3}{*}{$\begin{array}{c}0 / 28(0) \\
0 / 28(0) \\
2 / 28 \\
(7.2) \\
1 / 28 \\
(3.6)\end{array}$} \\
\hline & & & $90 / 6$ & & & 4.01 & 10.57 & \\
\hline & & & $70 / 8$ & & & 4.32 & 10.79 & \\
\hline & $\begin{array}{l}\text { In vivo model: } \\
\text { swine RA/RV } \\
\text { myocardium }\end{array}$ & QDOTMICRO $^{\mathrm{TM}}$ catheter & $90 / 4$ & 8 & 15 & $\begin{array}{l}\text { RA } 3.39 \\
\text { RV } 3.82\end{array}$ & $\begin{array}{l}\text { RA } 7.0 \\
\text { RV } 6.92\end{array}$ & $\begin{array}{c}3 / 174 \\
(1.7)\end{array}$ \\
\hline
\end{tabular}

HPSD: high-power short-duration; LV: left ventricle; RA: right atrium; RV: right ventricle.

observed one symptomatic esophageal ulcer in 402 patients undergoing HPSD ablation with $50 \mathrm{~W}$ for $2-5 \mathrm{~s}$ in their early experience. Chen et al. [23, 37] and Kaneshiro et al. [38] used AI (400) guiding HPSD (45-50 W) for the left atrial posterior wall and combined multisensory luminal esophageal temperature monitoring and postablation esophageal endoscopy. Chen et al. $[23,37]$ observed that the incidence of luminal esophageal temperature $>39^{\circ} \mathrm{C}$ was $47 \%$ (57/122), and the rate of endoscopically detectable lesion formation was 2 of 57 (3.5\%) without evident clinical sequelae. Kaneshiro et al. [38] compared HPSD ablation with CAT and found that the incidence of esophageal thermal injury was significantly higher in the HPSD group (37\% versus $22 \% ; P=0.011$ ), but the prevalence of esophageal lesions 
TABLE 2: The HPSD RF ablation settings and lesion endpoint in published clinical studies.

\begin{tabular}{|c|c|c|c|c|c|c|c|c|c|}
\hline \multirow{2}{*}{ Study } & \multirow{2}{*}{ Study type } & \multirow{2}{*}{$\begin{array}{l}\text { Sample } \\
\text { size }\end{array}$} & \multirow{2}{*}{ AF type } & \multirow{2}{*}{$\begin{array}{l}\text { Catheter } \\
\text { type }\end{array}$} & \multicolumn{2}{|c|}{$\begin{array}{l}\text { High power and } \\
\text { dwell time }\end{array}$} & \multirow{2}{*}{ Contact force } & \multirow{2}{*}{$\begin{array}{l}\text { Irrigation } \\
\text { flow rate }\end{array}$} & \multirow{2}{*}{$\begin{array}{l}\text { Lesion } \\
\text { endpoint }\end{array}$} \\
\hline & & & & & $\begin{array}{l}\text { Anterior } \\
\text { wall }\end{array}$ & $\begin{array}{l}\text { Posterior } \\
\text { wall }\end{array}$ & & & \\
\hline $\begin{array}{l}\text { Bunch et al. } \\
{[21]}\end{array}$ & $\begin{array}{l}\text { Controlled } \\
\text { study }\end{array}$ & 804 & $\begin{array}{l}\text { PAF and } \\
\text { PsAF }\end{array}$ & $\begin{array}{l}\text { Force- } \\
\text { sensing } \\
\text { catheter and } \\
\text { non-force- } \\
\text { sensing } \\
\text { catheter }\end{array}$ & $\begin{array}{l}50 \mathrm{~W} / \\
5-15 \mathrm{~s}\end{array}$ & $\begin{array}{l}50 \mathrm{~W} / \\
2-5 \mathrm{~s}\end{array}$ & $5-2 \mathrm{~g}$ & $30 \mathrm{ml} / \mathrm{min}$ & $\begin{array}{c}\text { Local } \\
\text { electrogram } \\
\text { and dwell time }\end{array}$ \\
\hline $\begin{array}{l}\text { Winkle } \\
\text { et al. [22] }\end{array}$ & $\begin{array}{l}\text { Cohort } \\
\text { study }\end{array}$ & 1,250 & $\begin{array}{l}\text { PAF and } \\
\text { PsAF and } \\
\text { long- } \\
\text { standing } \\
\text { AF }\end{array}$ & $\begin{array}{l}\text { Force- } \\
\text { sensing } \\
\text { catheter }\end{array}$ & $50 \mathrm{~W}$ & $50 \mathrm{~W}$ & $10-40 \mathrm{~g}$ & - & $\begin{array}{c}\text { Impedance } \\
\text { drop, loss of } \\
\text { pacing capture, } \\
\text { and LSI }\end{array}$ \\
\hline $\begin{array}{l}\text { Chen et al. } \\
\text { [23] }\end{array}$ & $\begin{array}{l}\text { Cohort } \\
\text { study }\end{array}$ & 50 & $\begin{array}{l}\text { PAF and } \\
\text { PsAF }\end{array}$ & $\begin{array}{c}\text { STSF } \\
\text { catheter }\end{array}$ & $50 \mathrm{~W}$ & $50 \mathrm{~W}$ & $\begin{array}{l}\text { Minimum force } \\
3 \mathrm{~g}\end{array}$ & $20 \mathrm{ml} / \mathrm{min}$ & AI \\
\hline $\begin{array}{l}\text { Vassallo } \\
\text { et al. [24] }\end{array}$ & $\begin{array}{l}\text { Controlled } \\
\text { study }\end{array}$ & 76 & $\begin{array}{l}\text { PAF and } \\
\text { PsAF }\end{array}$ & $\begin{array}{l}\text { Force- } \\
\text { sensing } \\
\text { catheter }\end{array}$ & $\begin{array}{c}50 \mathrm{~W} / 6- \\
8 \mathrm{~s}\end{array}$ & $\begin{array}{c}45 \mathrm{~W} / 6- \\
8 \mathrm{~s}\end{array}$ & $\begin{array}{l}10-20 \mathrm{~g}(\text { anterior }) / \\
5-10 \mathrm{~g} \text { (posterior) }\end{array}$ & $35 \mathrm{ml} / \mathrm{min}$ & $\begin{array}{l}\text { Impedance } \\
\text { drop }\end{array}$ \\
\hline $\begin{array}{l}\text { Okamatsu } \\
\text { et al. [25] }\end{array}$ & $\begin{array}{l}\text { Controlled } \\
\text { study }\end{array}$ & 60 & $\begin{array}{l}\text { PAF and } \\
\text { PsAF }\end{array}$ & $\begin{array}{c}\text { STSF } \\
\text { catheter }\end{array}$ & $50 \mathrm{~W}$ & $40 \mathrm{~W}$ & Minimum force $3 g$ & - & $\mathrm{AI}$ \\
\hline $\begin{array}{l}\text { Berte et al. } \\
{[26]}\end{array}$ & $\begin{array}{c}\text { Controlled } \\
\text { study }\end{array}$ & 174 & $\begin{array}{l}\text { PAF and } \\
\text { PsAF }\end{array}$ & $\begin{array}{c}\text { STSF } \\
\text { catheter }\end{array}$ & $45 \mathrm{~W}$ & $35 \mathrm{~W}$ & - & $15 \mathrm{ml} / \mathrm{min}$ & $\mathrm{AI}$ \\
\hline $\begin{array}{l}\text { Kottmaier } \\
\text { et al. [27] }\end{array}$ & $\begin{array}{c}\text { Controlled } \\
\text { study }\end{array}$ & 197 & PAF & $\begin{array}{l}\text { Flexibility SE } \\
\text { catheter }\end{array}$ & $70 \mathrm{~W} / 7 \mathrm{~s}$ & $70 \mathrm{~W} / 5 \mathrm{~s}$ & - & $20 \mathrm{ml} / \mathrm{min}$ & $\begin{array}{l}\text { Power and } \\
\text { dwell time }\end{array}$ \\
\hline $\begin{array}{l}\text { Reddy et al. } \\
\text { [28] }\end{array}$ & $\begin{array}{l}\text { Cohort } \\
\text { study }\end{array}$ & 52 & PAF & $\begin{array}{c}\text { STSF } \\
\text { catheter }\end{array}$ & $90 \mathrm{~W} / 4 \mathrm{~s}$ & $90 \mathrm{~W} / 4 \mathrm{~s}$ & $5-30 \mathrm{~g}$ & $8 \mathrm{ml} / \mathrm{min}$ & $\begin{array}{l}\text { Power and } \\
\text { dwell time }\end{array}$ \\
\hline $\begin{array}{l}\text { Pambrun } \\
\text { et al. [29] }\end{array}$ & $\begin{array}{l}\text { Controlled } \\
\text { study }\end{array}$ & 100 & PAF & $\begin{array}{l}\text { Force- } \\
\text { sensing } \\
\text { catheter }\end{array}$ & $50 \mathrm{~W}$ & $40 \mathrm{~W}$ & $\begin{array}{l}\text { Minimum force } \\
10 \mathrm{~g}\end{array}$ & - & $\begin{array}{l}\text { Unipolar signal } \\
\text { modification }\end{array}$ \\
\hline $\begin{array}{l}\text { Castrejón- } \\
\text { Castrejón } \\
\text { et al. [30] }\end{array}$ & $\begin{array}{l}\text { Controlled } \\
\text { study }\end{array}$ & 95 & $\begin{array}{l}\text { PAF and } \\
\text { PsAF }\end{array}$ & $\begin{array}{l}\text { Force- } \\
\text { sensing } \\
\text { catheter }\end{array}$ & $50-60 \mathrm{~W}$ & $50-60 \mathrm{~W}$ & $10 \mathrm{~g}$ & - & AI/LSI \\
\hline $\begin{array}{l}\text { Ejima et al. } \\
\text { [31] }\end{array}$ & $\begin{array}{l}\text { Controlled } \\
\text { study }\end{array}$ & 120 & PAF & $\begin{array}{c}\text { STSF } \\
\text { catheter }\end{array}$ & $50 \mathrm{~W}$ & $50 \mathrm{~W}$ & $10 \mathrm{~g}$ & - & $\begin{array}{l}\text { Unipolar signal } \\
\text { modification }\end{array}$ \\
\hline $\begin{array}{l}\text { Yazaki et al. } \\
{[32]}\end{array}$ & $\begin{array}{l}\text { Controlled } \\
\text { study }\end{array}$ & 64 & PAF & $\begin{array}{c}\text { STSF } \\
\text { catheter }\end{array}$ & $50 \mathrm{~W}$ & $50 \mathrm{~W}$ & - & - & $\begin{array}{l}\text { Unipolar signal } \\
\text { modification } \\
\text { and dwell time }\end{array}$ \\
\hline $\begin{array}{l}\text { Yavin et al. } \\
\text { [33] }\end{array}$ & $\begin{array}{l}\text { Controlled } \\
\text { study }\end{array}$ & 224 & $\begin{array}{l}\text { PAF and } \\
\text { PsAF }\end{array}$ & $\begin{array}{c}\text { STSF } \\
\text { catheter }\end{array}$ & $\begin{array}{c}45-50 / \\
15 s\end{array}$ & $45-50 / 8 s$ & - & $17 \mathrm{ml} / \mathrm{min}$ & $\begin{array}{l}\text { Impedance } \\
\text { drop }\end{array}$ \\
\hline $\begin{array}{l}\text { Ücer et al. } \\
{[35]}\end{array}$ & $\begin{array}{l}\text { Cohort } \\
\text { study }\end{array}$ & 25 & $\begin{array}{l}\text { PAF and } \\
\text { PsAF }\end{array}$ & $\begin{array}{c}\text { STSF } \\
\text { catheter }\end{array}$ & 50 & $50 / 6-10 s$ & $\begin{array}{c}10-15 \mathrm{~g} \\
\text { (posterior)/ } \\
15-20 \mathrm{~g} \text { (anterior) }\end{array}$ & 15 & $\begin{array}{l}\text { Power and } \\
\text { dwell time }\end{array}$ \\
\hline $\begin{array}{l}\text { Shin et al. } \\
{[34]}\end{array}$ & RCT & 150 & $\begin{array}{l}\text { PAF and } \\
\text { PsAF }\end{array}$ & $\begin{array}{c}\text { STSF } \\
\text { catheter }\end{array}$ & 50 & 50 & $20 \mathrm{~g}$ & 15 & $\begin{array}{l}\text { Power and } \\
\text { dwell time }\end{array}$ \\
\hline
\end{tabular}

AI: ablation index; AF: atrial fibrillation; LSI: lesion size index; PAF: paroxysmal atrial fibrillation; PsAF: persistent atrial fibrillation; RF: radiofrequency; STSF : SmartTouch surround flow.

did not differ between the two groups (7\% versus $8 \%$ ). In a study by Reddy et al. [28], esophageal ulcer hemorrhage was observed in one of 52 patients with RF application of $90 \mathrm{~W}$ for $4 \mathrm{~s}$ via postprocedural endoscopy on day 1, but it resolved with medication. In addition, esophageal injury observed using the postablation late gadolinium enhancement magnetic resonance imaging (MRI) in the HPSD approach ( $50 \mathrm{~W}$ for $5 \mathrm{~s}$ ) was reported to be similar in incidence and size to that in the CAT group, and there was no evidence of atrioesophageal fistula in either group [39]. Esophageal temperature spatial and temporal characteristics during HPSD ablation with $50 \mathrm{~W}$ for $6 \mathrm{~s}$ were evaluated using a 12-point esophageal temperature probe. It was reported that all lesions with significant luminal esophageal temperature increase $\left(>2^{\circ} \mathrm{C}\right)$ within $20 \mathrm{~mm}$ distance from a temperature sensor to a preexisting RF lesion returned to baseline temperature $\left( \pm 1^{\circ} \mathrm{C}\right)$ within $60 \mathrm{~s}$ after the cession of RF application, indicating that esophageal injury may be avoided if RF was not applied within $20 \mathrm{~mm}$ apart from a prior lesion for at least $60 \mathrm{~s}$ [40].

With regard to systemic emboli formation and steam pops, published studies cannot provide meaningful data on 


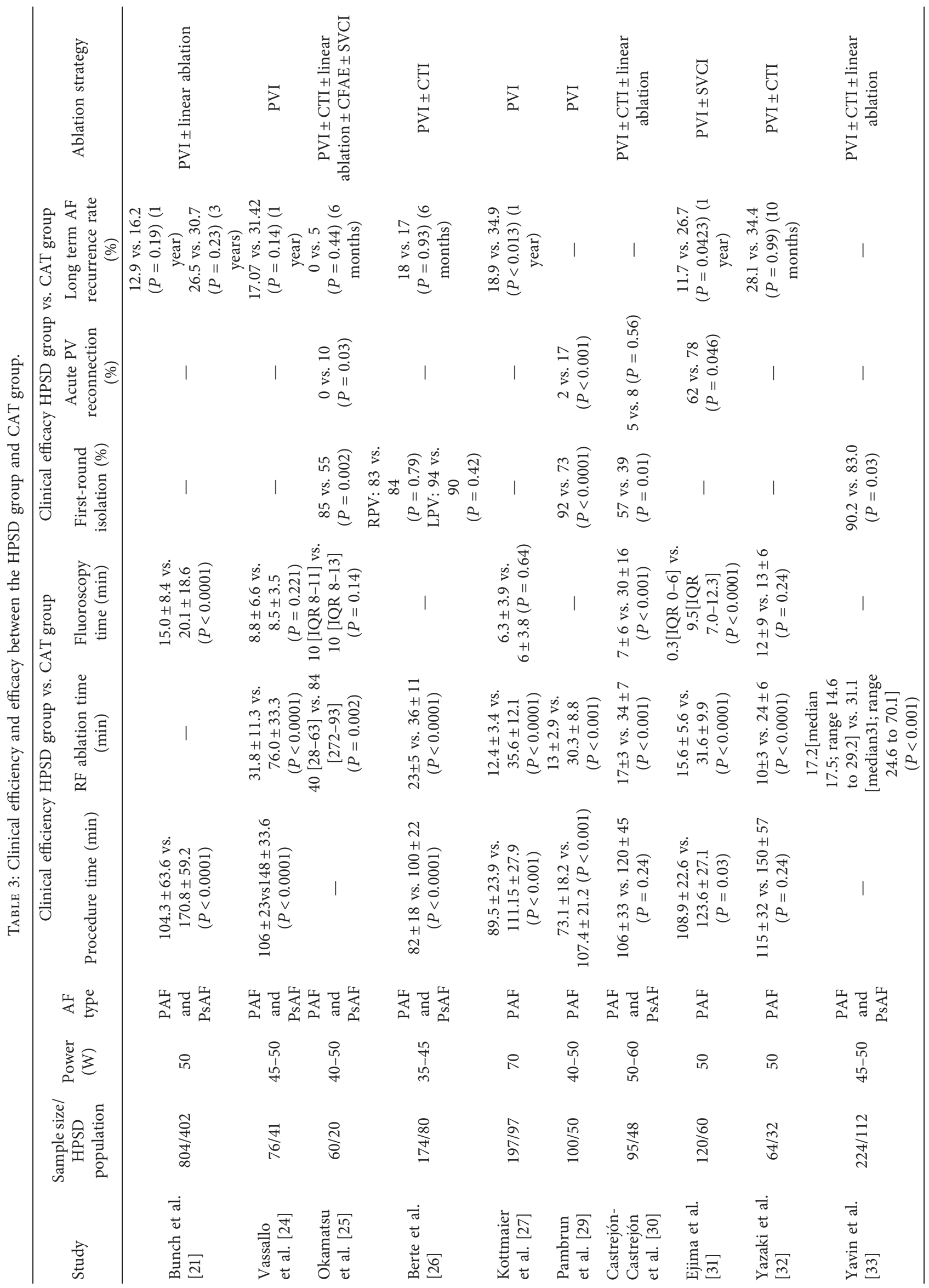




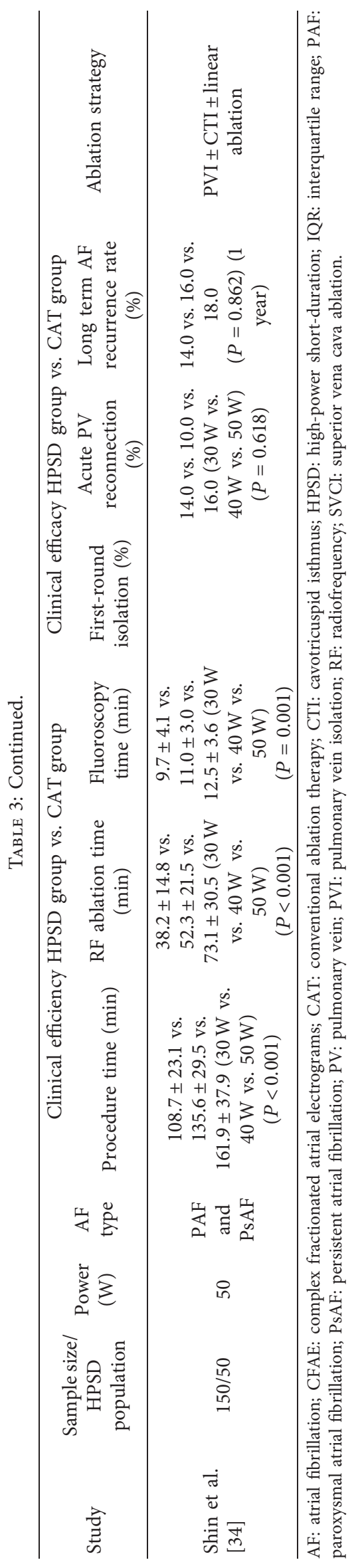


the risks because of the small volume of study patients. Reddy et al. [28] reported that, in six patients (11.5\%), silent cerebral lesions were detected but were not associated with neurologic deficits. Although most disappeared on repeat MRI after one to three months, whether potential impacts remained was uncertain. As for steam pops, Chen et al. [23,37] reported its occurrence in four patients $(3 \%$; 4/122) who underwent anterior wall ablation with $50 \mathrm{~W}$ for $550 \mathrm{AI}$ in the very first 50 cases, either because of high CF or long ablation duration, and no pericardial effusion or cardiac tamponade was observed. Castrejón-Castrejón et al. [30] observed steam pops in four patients (8.3\%) under HPSD ablation with 50-60 W, and none were observed in the conventional group. In Yavin et al.'s study [33], the incidence of steam pops in HPSD $(45-50 \mathrm{~W}, 8-15 \mathrm{~s})$ group was similar to the conventional group $(0.07 \%$ vs. $0.03 \% ; P=0.18)$. In both studies, no related clinical injury occurred. It seems that the incidence of steam pops is increasing to some extent, but they have not been found to result in clinical injuries.

\section{Limitations and Future Perspectives}

A number of experimental and clinical studies have revealed the efficiency, safety, and efficacy results of the HPSD approach in patients undergoing AF ablation. HPSD ablation is reported to have equivalent or superior procedural efficiency and clinical outcomes compared with conventional ablation. With regard to safety issues, published data cannot provide powerful and substantial evidence, mainly limited to the sample size. It is still worthwhile to anticipate whether the HPSD approach is a game-changing technique for patients with AF.

There has been no comparison of HPSD ablation with CBA or PFA. CBA is performed in a single-step mode, leading to necrosis by freezing and thawing [3]. It is noninferior to RFCA with respect to efficacy and overall safety. With regard to procedural efficiency, CBA requires shorter procedure time (124.4 \pm 39.0 vs. $140.9 \pm 54.9 \mathrm{~min})$ but longer fluoroscopy time $(21.7 \pm 13.9$ vs. $16.6 \pm 17.8 \mathrm{~min})$ than the conventional RFCA strategy [3]. Comparison between CBA and HPSD RF ablation is still lacking. PFA uses highvoltage-pulsed electrical fields to ablate myocardium through the mechanism of irreversible electroporation [6]. A single PFA delivery is accomplished within a heartbeat and it is estimated that the time required to deliver the PFA energy for complete PVI amounted to no more than 3 min per patient [6]. In contrast with HPSD RF ablation, the effects of PFA are almost instantaneous.

Until now, only one randomized controlled trial has been performed, but it does not adequately prove the purported benefits of the HPSD approach, especially in clinical efficacy. A standard HPSD approach is not defined, including RF application settings, local endpoint, workflow, and so on. HPSD ablation is currently used by experienced operators and centers $[41,42]$. In addition, long-term outcomes are required to verify its clinical benefits. Some studies have worked on the HPSD approach by compromising high power for a high-irrigation profile, which requires more evidence to clarify its safety. All the aforementioned critical questions need to be answered adequately before the widespread adoption of the HPSD approach.

\section{Conclusions}

RF energy ablation delivered at a high power (45-90 W) for a short duration remarkably improves the procedural efficiency. Compared with CAT, HPSD ablation probably contributes to a higher rate of first-pass isolation and a lower acute PV reconnection rate. Current studies have not provided substantial evidence on long-term outcomes and safety profiles. Further research on the HPSD approach is required to estimate its safety and efficacy, compared with CAT.

\section{Data Availability}

The data used to support the findings of this study are included within the review.

\section{Conflicts of Interest}

The authors declare that there are no conflicts of interest regarding the publication of this paper.

\section{Authors' Contributions}

Dr. Xuerong Sun and Dr. Jiang Lu contributed equally to the article.

\section{Acknowledgments}

The authors would like to thank Hao Zhao, MD for illustration support (Figure 1). This study was supported by the Capital Clinically Characteristic Applied Research Fund (Z181100001718210) and Clinical and Translational Fund of Chinese Academy of Medical Sciences (2019XK320060).

\section{References}

[1] A. Verma, C.-y. Jiang, T. R. Betts et al., "Approaches to catheter ablation for persistent atrial fibrillation," New England Journal of Medicine, vol. 372, no. 19, pp. 1812-1822, 2015.

[2] J. Chen, S. Willems, A. Sultan et al., "Pulmonary vein isolation versus defragmentation," Journal of the American College of Cardiology, vol. 66, no. 24, pp. 2743-2752, 2015.

[3] K.-H. Schreiber, J. Brugada, A. Fürnkranz et al., "Cryoballoon or radiofrequency ablation for paroxysmal atrial fibrillation," New England Journal of Medicine, vol. 374, no. 23, pp. 2235-2245, 2016.

[4] J. Metzner, T. Strisciuglio, M. El Haddad et al., "Pulmonary vein reconnection no longer occurs in the majority of patients after a single pulmonary vein isolation procedure," JACC: Clinical Electrophysiology, vol. 5, no. 3, pp. 295-305, 2019.

[5] T. Wolf, P. Taghji, M. El Haddad et al., "Improving procedural and one-year outcome after contact force-guided pulmonary vein isolation: the role of interlesion distance, ablation index, and contact force variability in the "CLOSE"-protocol," Europace, vol. 20, pp. 419-427, 2018.

[6] V. Y. Metzner, P. Neuzil, J. S. Koruth et al., "Pulsed field ablation for pulmonary vein isolation in atrial fibrillation," Journal of the American College of Cardiology, vol. 74, no. 3, pp. 315-326, 2019. 
[7] T. Petru, P. Halbfaß, and H. Pürerfellner, "High-power short duration ablation for pulmonary vein isolation: simply cranking up the energy?" EP Europace, vol. 22, no. 3, pp. 335-337, 2020.

[8] A. Lee and E. P. Gerstenfeld, "High-power radiofrequency ablation for atrial fibrillation: establishing a standardized protocol," Journal of Cardiovascular Electrophysiology, vol. 30, no. 12, pp. 2732-2733, 2019.

[9] P. J. Patel and B. J. Padanilam, "High-power short-duration ablation: better, safer, and faster?" Journal of Cardiovascular Electrophysiology, vol. 29, no. 11, pp. 1576-1577, 2018.

[10] M. Barkagan, F. M. Contreras-Valdes, E. Leshem, H. Nakagawa, and E. Anter, "High-power and short-duration ablation for pulmonary vein isolation: safety, efficacy, and long-term durability," Journal of Cardiovascular Electrophysiology, vol. 29, no. 9, pp. 1287-1296, 2018.

[11] E. Buxton, I. Zilberman, C. M. Tschabrunn et al., "High-power and short-duration ablation for pulmonary vein isolation," JACC: Clinical Electrophysiology, vol. 4, no. 4, pp. 467-479, 2018.

[12] F. Barkagan, V. Goyal, M. Patel, D. E. Haines, and W. S. Wong, "High-power, low-flow, short-ablation durationthe key to avoid collateral injury?" Journal of Interventional Cardiac Electrophysiology, vol. 55, no. 1, pp. 9-16, 2019.

[13] A. Orelaru, W. Chik, J. Pouliopoulos et al., "Five seconds of 50-60 W radio frequency atrial ablations were transmural and safe: an in vitro mechanistic assessment and force-controlled in vivo validation," Europace, vol. 19, pp. 874-880, 2017.

[14] F. Squara, D. G. Latcu, Y. Massaad, S.-S. Bun, and N. Saoudi, "Contact force and force-time integral in atrial radiofrequency ablation predict transmurality of lesions," Europace, vol. 16, no. 5, pp. 660-667, 2014.

[15] N. Mahjoub, T. Kato, S. Sakagami et al., "Optimal lesion size index to prevent conduction gap during pulmonary vein isolation," Journal of Cardiovascular Electrophysiology, vol. 29, no. 12, pp. 1616-1623, 2018.

[16] J. S. Saeki, S. Kapur, C. Barbhaiya et al., "Sites with small impedance decrease during catheter ablation for atrial fibrillation are associated with recovery of pulmonary vein conduction," Journal of Cardiovascular Electrophysiology, vol. 27, no. 12, pp. 1390-1398, 2016.

[17] K. Kumar, K. Uno, H. Fujiwara, and Y. Iesaka, "Local unipolar and bipolar electrogram criteria for evaluating the transmurality of atrial ablation lesions at different catheter orientations relative to the endocardial surface," Heart Rhythm, vol. 7, no. 9, pp. 1291-1300, 2010.

[18] A. Isobe, A. Appetiti, A. Bouzeman et al., "Unipolar signal modification as a guide for lesion creation during radiofrequency application in the left atrium," Circulation: Arrhythmia and Electrophysiology, vol. 6, no. 6, pp. 1095-1102, 2013.

[19] A. Maupas, G. Brault-Noble, and A. Appetiti, "Elimination of the negative component of the unipolar atrial electrogram as an in vivo marker of transmural lesion creation," Circulation: Arrhythmia and Electrophysiology, vol. 8, no. 4, pp. 905-911, 2015.

[20] P. Marijon, M. El Haddad, T. Phlips et al., "Evaluation of a strategy aiming to enclose the pulmonary veins with contiguous and optimized radiofrequency lesions in paroxysmal atrial fibrillation," JACC: Clinical Electrophysiology, vol. 4, no. 1, pp. 99-108, 2018.

[21] T. J. Wolf, H. T. May, T. L. Bair et al., "Long-term outcomes after low power, slower movement versus high power, faster movement irrigated-tip catheter ablation for atrial fibrillation," Heart Rhythm, vol. 17, no. 2, pp. 184-189, 2020.

[22] R. A. Crandall, R. H. Mead, G. Engel et al., "High-power, short-duration atrial fibrillation ablations using contact force sensing catheters: outcomes and predictors of success including posterior wall isolation," Heart Rhythm, vol. 17, no. 8, pp. 1223-1231, 2020.

[23] S. Kong, B. Schmidt, S. Bordignon et al., "Ablation indexguided $50 \mathrm{~W}$ ablation for pulmonary vein isolation in patients with atrial fibrillation: Procedural data, lesion analysis, and initial results from the FAFA AI high power study," Journal of Cardiovascular Electrophysiology, vol. 30, no. 12, pp. 27242731, 2019.

[24] F. Urbanek, C. Cunha, E. Serpa et al., "Comparison of highpower short-duration (HPSD) ablation of atrial fibrillation using a contact force-sensing catheter and conventional technique: Initial results," Journal of Cardiovascular Electrophysiology, vol. 30, no. 10, pp. 1877-1883, 2019.

[25] H. Meigre, J. Koyama, Y. Sakai et al., "High-power application is associated with shorter procedure time and higher rate of first-pass pulmonary vein isolation in ablation index-guided atrial fibrillation ablation," Journal of Cardiovascular Electrophysiology, vol. 30, no. 12, pp. 2751-2758, 2019.

[26] B. Negishi, G. Hilfiker, I. Russi et al., "Pulmonary vein isolation using a higher power shorter duration CLOSE protocol with a surround flow ablation catheter," Journal of Cardiovascular Electrophysiology, vol. 30, no. 11, pp. 2199-2204, 2019.

[27] M. Moccetti, M. Popa, F. Bourier et al., "Safety and outcome of very high-power short-duration ablation using $70 \mathrm{~W}$ for pulmonary vein isolation in patients with paroxysmal atrial fibrillation,” EP Europace, vol. 22, no. 3, pp. 388-393, 2020.

[28] V. Y. Reents, M. Grimaldi, T. De Potter et al., "Pulmonary vein isolation with very high power, short duration, temperaturecontrolled lesions," JACC: Clinical Electrophysiology, vol. 5, no. 7, pp. 778-786, 2019.

[29] T. Vijgen, C. Durand, M. Constantin et al., "High-power (40-50 W) radiofrequency ablation guided by unipolar signal modification for pulmonary vein isolation: experimental findings and clinical results," Circulation: Arrhythmia and Electrophysiology, vol. 12, Article ID e007304, 2019.

[30] S. Castrejón-Castrejón, M. Martínez Cossiani, M. Ortega Molina et al., "Feasibility and safety of pulmonary vein isolation by high-power short-duration radiofrequency application: short-term results of the POWER-FAST PILOT study," Journal of Interventional Cardiac Electrophysiology, vol. 57, no. 1, pp. 57-65, 2020.

[31] K. Escobar, S. Higuchi, K. Yazaki et al., "Comparison of highpower and conventional-power radiofrequency energy deliveries in pulmonary vein isolation using unipolar signal modification as a local endpoint," Journal of Cardiovascular Electrophysiology, vol. 31, no. 7, p. 1702, 2020.

[32] K. Kataoka, K. Ejima, M. Kanai et al., "Impedance drop predicts acute electrical reconnection of the pulmonary vein-left atrium after pulmonary vein isolation using shortduration high-power exposure," Journal of Interventional Cardiac Electrophysiology, vol. 59, no. 3, p. 575, 2020.

[33] H. D. Kataoka, E. Leshem, A. Shapira-Daniels et al., "Impact of high-power short-duration radiofrequency ablation on long-term lesion durability for atrial fibrillation ablation," JACC: Clinical Electrophysiology, vol. 6, no. 8, pp. 973-985, 2020.

[34] D. G. Kaufmann, J. Ahn, S.-J. Han, and H. E. Lim, “Efficacy of high-power and short-duration ablation in patients with atrial 
fibrillation: a prospective randomized controlled trial," $E P$ Europace, vol. 22, no. 10, pp. 1495-1501, 2020.

[35] E. Ücer, C. Jungbauer, C. Hauck et al., "The low acute effectiveness of a high-power short duration radiofrequency current application technique in pulmonary vein isolation for atrial fibrillation," Cardiology Journal, 2020.

[36] R. A. Winkle, S. Mohanty, R. A. Patrawala et al., "Low complication rates using high power $(45-50 \mathrm{~W})$ for short duration for atrial fibrillation ablations," Heart Rhythm, vol. 16, no. 2, pp. 165-169, 2019.

[37] S. Mead, K. R. J. Chun, S. Tohoku et al., "Esophageal endoscopy after catheter ablation of atrial fibrillation using ablation-index guided high-power," JACC: Clinical Electrophysiology, vol. 6, no. 10, pp. 1253-1261, 2020.

[38] T. Bordignon, M. Kamioka, N. Hijioka et al., "Characteristics of esophageal injury in ablation of atrial fibrillation using a high-power short-duration setting," Circulation: Arrhythmia and Electrophysiology, vol. 13, Article ID e008602, 2020.

[39] A. Baher, M. Kheirkhahan, S. J. Rechenmacher et al., "Highpower radiofrequency catheter ablation of atrial fibrillation," JACC: Clinical Electrophysiology, vol. 4, no. 12, pp. 1583-1594, 2018.

[40] C. R. Marashly, E. V. Kogan, L. Jankelson et al., “Esophageal temperature dynamics during high-power short-duration posterior wall ablation," Heart Rhythm, vol. 17, no. 5, pp. 721-727, 2020.

[41] C. F. Knotts, J. Wu, C. L. Jin, M. J. Liu, and Y. Z. Xu, "Comparison of high-power short-duration and low-power long-duration radiofrequency ablation for treating atrial fibrillation: systematic review and meta-analysis," Clinical Cardiology, vol. 43, no. 12, p. 1631, 2020.

[42] C. L. Jin, M. F. Li, J. Wu, C. F. Chen, and Y. Z. Xu, "Safety and efficacy of high power shorter duration ablation for atrial fibrillation: a systematic review and meta-analysis," International Journal of Clinical Practice, Article ID e13732, 2020. 